\title{
Thought of the Dakwah M.Quraish Shihab
}

\author{
DR. Muhammad Salman Palewai, S. Ag., M.Ag. \\ Widyaiswara Balai Diklat Keagamaan Makassar Indonesia \\ Email: salman_palewai@yahoo.co.uk
}

Prof. Dr. M. Quraish Shihab is an expert in the field of Ulumul Qur'an and one of the Muslim scientists who actively expresses his thoughts through writing. He has written at least 50 books and received positive responses from the public. Some of his works are in the best seller category and printed many times. "Tafsir Al-Misbah" is his spectacular work which consists of fifteen volumes. This article expresses his thoughts on dakwah. The author examines several of his books that discuss the dakwah and its interpretation of the concept or method of preaching the Qur'an. The results of this study found that he divided the dakwah in two parts, namely al-Ittisal Ghairu al-Lafdzy and al-Ittisal al-lafdzy. Likewise, based on the chronology of the verse about the dakwah command to the Prophet, he concluded that the content and methods cannot be separated from the preacher. Similarly, the dakwah content is not out of date then the breadth of absolute insight, that is what the first verse hinted down. In terms of the method of dakwah, he distinguishes according to the conditions of mad'u based on the interpretation of surah An-Nahl verse 125. In terms of content, he does not agree with some preachers such as a description of the events of the migration of the Prophet Muhammad who emphasized the supernatural dimension. Furthermore he argued verse 120 of Surah Al-Baqarah as a basis for apostasy efforts, and verse 33 of Surah Ar-Rahman as a commandment to seek knowledge as often preached by some preachers. This article is expected to add to the treasury of knowledge, especially the guidance of the Koran (Al-Qur'an) in the implementation of dakwah so that it can be accepted by both Muslim and non-Muslim as dakwah objects.

Keywords: Dakwah thoughts, Quraish Shihab, Dakwah verses.

\section{Introduction}

\section{A. Background of the study}

By now, the Islamic religion has been spreaded and developed. Based on 2012 data, total Muslim population worldwide has reached 1.57 billion. It is because of the awareness of Muslims to carry out the task of preaching in accordance with their capacities and abilities. The command to preach in Islam is not a mandated duty to a particular person or group, but to anyone who feels his soul is called to fulfill it. According to Prof. Max Muller, when viewed from the standpoint of the doctrine of the dakwah of the major religions in the world, it may be classified into two parts, namely the preaching religion and the non-preaching religion. The first part are Islam, Buddhism, and Christianity. The second ones are Jews, Brahmas and Zoroaster. Preaching religion is intended to instill in adherents to spread their beliefs and invite others to embrace the religion they hold, the activity is considered a sacred duty from God.

Based on this viewpoint, Islam is categorized as a religion of dakwah. In nașh there are many commands to carry out dakwah. However, some people, even Muslims themselves, consider the scope of Islamic studies narrowly. They assume, Islam only regulates human relations with God or matters of worship (in the narrow sense). The impact of these thoughts, a measure of one's piety either good or bad is only seen rather than worshiping the vertical relationship of humans with God. When in fact Islam is a religion that perfectly regulates and organizes all aspects of human life, not only human relationship but also relationships between human with the natural surroundings.

The teachings of Islam are expected to be grounded in reality, to feel their existence, to be a reference or solution to the problems faced by people, both spiritual and educational, social, political, and civilization problems. Thus the people feel the need to recognize and practice religious teachings. Undeniably sometimes dakwah content is not able to be connected with the reality of daily socio-economic life such as environmental damage, the rise of unemployment and the limited employment opportunities, juvenile delinquency and so on. Therefore, the implementation of dakwah should be done in the best way, by focusing to the Qur'an dakwah verses both explicitly and implicitly. Likewise, the elements of dakwah are studied in depth so that preaching does not seem to be done casually. Some others important factors are by knowing and applying the communication and rhetoric skills, so that the dakwah can run effectively.

M. Quraish Shihab as one of the scholars, through his writings have much contributed to the thought of carrying out the ideal of preaching. This article describes his thoughts eitherhis Al-Qur'an verses interpretation or his paper, especially about dakwah. Likewise, he presented a bit of his different opinion from some other preachers' perceive.

112 


\section{B. Problem Statement}

Based on the studies background, followings are the problem statements:

1. How is the rule of preach according to M. Quraish Shihab?

2. How is the interpretation of the Holy Al-Qur'an Surah Al-Nahl verse number 125accordinh to M. Quraish Shihab?

3. How is the Preachers' Characteristics based on the Holy Al-Qur'an?

\section{Discussion}

\section{A. Curriculum Vitae and Work of M. QuraishShihab}

Prof. Dr. M. Quraish Shihab was born in Rappang, South Sulawesi, February $16^{\text {th }} 1944$, is an Indonesian Muslim scholar and famous as an expert in al-Qur'an interpretation. His formal education in junior high school was pursued at the Darul Hadis al-Falaqiyah Islamic Boarding School in Malang. To further his Islamic studies, he was sent by his father to al-Azhar, Cairo, in 1958 and accepted into the second grade Tsanawiyah. After that, he continued his studies at al-Azhar University on the Ushuluddin faculty of Tafsir and Hadith. In 1976 he earned his M.A. with a thesis titled al-I'jaz at-Tasyri li Al-Qur'an al-Karim. To realize his ideals of deep study of interpretation, in 1980 he studied at his alma mater, al-Azhar. He only needed two years to get a doctorate in this field. His dissertation entitled Nazmad Durr li al Biqa'i Tahqiqwa Dirasah (A Study of the Book of Nazmad Drar ad-Duurar (Pearl Series) by al-Biqa'i) was successfully defended with the title of summa cum laude with the award of Mumtäzma'amartabah ash-syarf al-üla (exemplary scholar with special achievements).

After returning home, he returned to his original assignment, IAIN Alauddin Ujung Pandang, however, two years later (1984) he was withdrawn to Jakarta as a lecturer at the Faculty of Usuluddin and Fakultas Post-graduate IAIN Syarif Hidayatullah. In 1994-1998 he was entrusted as Chancellor. In 1998, he served as minister of religion for two years, before being appointed as an ambassador in Egypt. It was the time he created his spectacular work, Tafsir Al-Misbah, which consisted of 15 volumes.

In addition to the commentary work, followings are his 42 books' title: Wawasan al-Qur'an (Mizan, 1996), Secercah Cahaya Ilahi (Mizan, 2000), Menyingkap Tabir Ilahi: al-Asmâ' al-Husnâ dalam Perspektif al-Qur'an (LenteraHati, 1998), Yang Tersembunyi: Jin, Malaikat, Iblis, Setan (LenteraHati, 1999), Jilbab: PakaianWanitaMuslimah, Pandangan Ulama Masa Lalu dan Cendekiawan Kontemporer (LenteraHati, 2004), Perempuan (Dari Cinta Sampai Seks, Dari Nikah Mut'ah sampai Nikah Sunnah, Dari Bias Lama sampai Bias Baru) (LenteraHati, 2004), Pengantin al-Qur'an (LenteraHati, 2007), Mahkota Tuntunan Ilahi: Tafsir Surah al-Fâtihah (Untagma, 1988), Tafsir al-Qur'an al-Karim: Tafsiratas Surah-surah Pendek Berdasarkan Urutan Turunnya Wahyu (Pustaka Hidayah, 1997), Perjalanan Menuju Keabadian: Kematian, Surga, dan Ayat-Ayat Tahlil (LenteraHati, 2001), Menjemput Maut: Bekal Perjalanan Menuju Allah SWT. (LenteraHati, 2002), Al-Lubâb: Makna, Tujuan, dan Pelajaran dari Surah-Surah al-Qur'an (Lentera Hati, 2012), Al-Qur'an dan Maknanya (Lentera Hati, 2010), Membumikan al-Qur'an (Mizan, 1992), Lentera Hati (Mizan, 1994), Menabur Pesan Ilahi: Al-Qur'an dan Dinamika Kehidupan Masyarakat (Lentera Hati, 2006), Membumikan alQur'an Jilid 2 (LenteraHati, 2011), Tafsir al-Manar: Keistimewaan dan Kelemahannya (IAIN Alauddin, 1984), Studi Kritis Tafsir Al-Manar, Karya Muhammad Abduhdan M. Rasyid Ridha (diterbitkan kembali oleh Pustaka Hidayah Bandung, 1994), Rasionalitas al-Qur'an: Studi Kritisatas Tafsir al-Manar (diterbitkan kembali oleh Lentera Hati, 2005), Filsafat Hukum Islam (Departemen Agama, 1987), Mukjizat al-Qur'an (Mizan, 1996), KaidahTafsir (Lentera Hati, 2013), Haji Bersama M. QuraishShihab (Mizan, 1998), Dia di Mana-Mana (LenteraHati, 2004), Wawasan al-Qur'an tentang Zikir dan Doa (Lentera Hati, 2006), Logika Agama: Kedudukan Wahyu dan Batas-Batas Akal dalam Islam (Lentera Hati, 2005), Sunnah-Syiah Bergandengan Tangan! Mungkinkah? Kajian atas Konsep Ajaran dan Pemikiran (Lentera Hati, 2007), Yang Ringan Jenaka (Lentera Hati, 2007), Yang Sarat dan yang Bijak (Lentera Hati, 2007), M. Quraish Shihab Menjawab 1001 Soal Keislaman yang Patut Anda Ketahui (Lentera Hati, 2008), Ayat-Ayat Fitnah : Sekelumit Keadaban Islam di Tengah Purbasangka (Lentera Hati dan Pusat Studi al-Qur'an, 2008), Berbisnis dengan Allah (Lentera Hati, 2008), Doa Harian bersama M. Quraish Shihab (Lentera Hati, 2009), M. Quraish Shihab Menjawab 101 SoalPerempuan yang Patut Anda Ketahui (Lentera Hati, 2010), Membaca Sirah Muhammad SAW dalam Sorotan al-Qur'an dan Hadits-Hadits Shahih (LenteraHati, 2011), Doa Asmaul Husna:

Doa yang Disukai Allah (Lentera Hati, 2011), Haji dan Umrah Bersama M. Quraish Shihab (Lentera Hati, 2012), Kematian adalah Nikmat (Lentera Hati, 2013), M. Quraish Shihab Menjawab pertanyaan Anak tentang Islam (Lentera Hati, 2014), Birrul Walidain (Lentera Hati, 2014) Islam Yang Saya Anut (Lentera Hati, 2018), Islam Yang Saya Pahami (LenteraHati, 2018). Islam Yang Disalahpahami, (2019) Jawaban Adalah Cinta (2019) Yang Hilang Dari Kita (2019) Almaidah 51 Satu Firman Beragam Penafsiran (2019) Wasathiyyah Wawasan Islam tentang Moderasi Beragama (2019), Kosa Kata Kegamaan (2020). 


\section{B.TheUrgence and Obligation to preach}

In human being unites physical as well as spiritual elements, and naturally has a selfish character (egoism), but at the same time has a social character such as willing to help (ta'awun) and cooperate one another. Then humans have elements nasut (humanity) and malakut. Human physical originating from matter which has the necessity of material needs, while the spiritual which is immaterial has spiritual ones. In order to make an equality of the world and the hereafter happiness in human's, it is necessary to instill faith. By this point, dakwah becomes a human need. Epistemology, the word of dakwah comes from the Arabic word dakwah, a masdar form of the verb da'a (madhi), yad'ü, meaning an invitation by voice or speech. For example dakwatu ila thām, (meal invitation). However, Terminology, dakwah means an effort and an invitation to God through either words or deeds. The particular point is the invitation to practice the teachings of Islam, Sayyid Quthubin A.Ilyas Ismail stated that dakwah is (the invitation) to worship Allah, neither to worship preachers nor their people. There is no preach except to carry out its duties and obligations to worship Allah SWT. As God's invitation, preaching according to Qutub, is an invitation to a perfect form of life, life in all forms of all its perfect meanings.

Based on the explanation above, it could be understood that preaching is a sacred duty that aims to draw people closer to God through the practice of Islamic teachings. The invitation is not only limited to words but also actions or role of models.

Dakwah is more specifically explained by M. Quraish Shihab as an appeal or an invitation to a consciousness, or an effort to change the situation to be a better situation, both to the person and the community. It is further emphasized that the expected result of carrying out the dakwah is a change and improvement not only in understanding and outlook on life, but should lead to the implementation of Islamic teachings more thoroughly in various aspects of life.

The orientation of a dakwah is the impression (atsar) which is able to color the souls of the mad'u and then be imprinted in action. This view straighten of people who always judge a good dakwah is when the listener sobs, or gets a clap, even leads them to laugh out loud even though the preachers tell the stories of Israiliyat or Da'eef hadiths. Some consider that a good dakwah is a criticizing to the government. Ironically, according to him, the preacher is sometimes influenced by a such evaluations. This is what causes the preachers to reduce their listeners to the level. Whereas, the preacher is expected to raise his audience to a higher level. Therefore, to achieve the ideal goal of carrying out dakwah, all elements of dakwah should be concerned.

According to him, there are two indicators of the dakwah success. First, if mad'u gets a new understanding and sticks to his mind, either something that was previously unknown, or he already knew but misunderstood (refinement). Second, he may already know but not memorable in his heart nor practiced, preaching led them to practice or avoid something prohibited. Dakwah is ideal if both of these can be achieved.

The obligation to preach is based on the word of God in the Holy Al-Qur'an surah Äli Imran verse number 104. Scholars differ about whether dakwah is included in the fardu ain orfardu kifayah categories. In the verse, there is the word min. Scholars who argue that the task of preaching as fardkifayah, the word is interpreted partly orli al-tab'id). When those who believe it as fard 'ain, it is interpreted as an explanation or li al-bayan. For those who argue that dakwah as fard kifayah, one of the reasons is that not everyone is able to fulfill the task due to limited knowledge or physical disability. As for the dakwah which includes invitations to the good, ordering the good and preventing the evil, depth of knowledge is needed. It is feared that if these conditions are not owned, it can lead to errors in fulfilling them which can result in worse conditions.

As for the reasons for those who understand it as fard ain as revealed by Yusuf al-Qaradhawi, the task of preaching is an obligation that applies to all Muslims, he connects it with the closing verse of the surah' Ali Imrān verse number 104. According to him, those who call for virtue and prevent to ignore, they are lucky.

Luck is the hope of all individuals without exception, thus in order to achieve that noble goal it must also be that each individual goes his way that is carrying out the task of preaching.

Although Yusuf al-Qaradhawi believes that all Muslims have an obligation to carry out dakwah in general, but there should be a group of Muslims who become $d a^{\prime} i$ in particular. The case is the knowledge internalization that must be delivered to the community as an application of the word of Allah SWT: Al-Qur'an, surah At-Tawbah verse number 122.

Responding to the differences of scholars' opinions, according to the writers which is instilled to the public that dakwah is a sacred duty. To perpetuate Islamic values, each individual must take a part in accordance with their respective abilities. The dakwah field is really very broad according to the broad scope of the teachings of Islam which 
consists of public and special worship. For the practice of public worship dakwah, all individuals should take part in various forms such as lectures, performances, writings and that are not less important through good sampler.

As for the teachings of Islamic specific worship, it could be given to the experts, the scholars who prioritize time and attention for dakwah. On the contrary, it will cause problems if every Muslim, without being based on the depth Islamic science, taking an opinion or having an opinion (fatwa) on religious matters outside the specialization of his knowledge.

From these two views, M. Quraish Shihab stands that it is more appropriate to understand the word min kum in the verse in the sense of being a part of you, understand the word min kum in the verse in the sense of being a part of you. According to him, if dakwah in that verse is the perfect implementation of dakwah, there are less people to do it. The social needs today concerning the correct information as well, even the role of information that is so rapid with the presentation of new values that are often confusing, are required a special group to handle the dakwah and to censor the misleading information. However, it is not intended to deny the obligation to remind one another, based on the words of Allah SWT in surah al- 'Ashr which assesses all human beings in harm, except those who believe and do good deeds and remind each other about truth and fortitude.

\section{The Preachers' Characteristics and Preparation}

According to the communication expert, dakwah is a special communication. The elements of communication are also found in the dakwah process. Among the five elements, the preacher is the most important and strategic element, because the preacher must understand and carry out all strategic steps such as getting to know you, planning messages, setting methods and choosing media. Therefore $D a^{\prime} i$ has the role of conveying certain ideas towards the main goal, namely the acceptance of these ideas. So that there is a change in attitude or the existence of an inauguration of certain attitudes (reinforcement). Thus, the preacher is the main actor to influence the attitude change of the communicant, known as the agent of change.

To achieve these goals, preachers must have trust in the eyes of the community. In terms of communication science is the communicator's credibility. According to Berlo, a person's credibility can arise if they have: (1) communication skills (2) knowledge, which is broad knowledge about the substance delivered (3) attitude, namely honest and friendly attitudes, and (4) social and cultural system, which is able to adapt to social and cultural systems.

In the meantime, based on the interpretation of several verses of the Holy Qur'an, M. Quraish Shihab formulates the characteristics of $d a^{\prime} i$, namely, full of sincerity, tough aqeedah, patient, and knowledgeable, and respects to the diversity. His view is based on the interpretation of surah Yusuf verse number 108, surah Al-Alaq verse number 1, and surah Al-Muddatstsir verses number 3-7.

In verse number 108 of the surah Yusuf, it is mentioned the Prophet Muhammad first and then his followers. In that verse implies that the Prophet is a model in the implementation of dakwah, although it was realized that it is impossible to equal it. This is because Rasulullah SAW has reached the peak in dakwah and fully fulfills the guidance of Allah SWT. He delivered Ala bashirah dakwah, which means based on the clear evidence accompanied by full sincerity. The breadth of a preacher's knowledge, according to him, is the chronologically of the verses were sent down. The reading instruction comes before the assignment conveys dakwah, while personal coaching and attractive appearance come together with the task of delivering dakwah. This means that the methods and content of dakwah cannot be separated from the preacher, as this shows that a preacher should have adequate insight before preaching. It was obtained, by reading so that what was conveyed was not out of date, or boring and certainly delivered it with a harmonious appearance, full of optimism, sincerity and courage and courageous but wise. The breadth of insight, appearance, and personal power is in the term of al-Ittishal Ghairu al-Lafdzy.

More detailed instructions on the implementation of dakwah are based on the early surah al Muddatsir. The first clue is based on verse 3 (And your Lord, glorify Him). According to him, one of the glorifying God is embedded in his soul the awareness of the smallness of something other than God, even though it is big or great. And at the same time he felt strong and was able to face all challenges because he had hung his body and soul to the Most Great. Until then, he will not ask for protection except from Him.

This principle is very important to bring the soul of courage and submission to him. Without adhering to this principle, it will not be possible for someone to be able to fulfill dakwah well. Because it has become a sunnatullah, this is the implementation of dakwah is faced with challenges and obstacles. Al-Qur'an tells the journey of the previous apostles who faced many threats, but with that principle no matter how heavy the challenge of preaching, they succeeded in carrying it out. That is why this was first implanted in the Prophet Muhammad. 
The second principle, "Clean your clothes", he believes a preacher should look attractive. In the first clue, it is emphasized mental development. In this fourth verse, the emphasis is outward appearance in order to attract the sympathy of those who are given warning and guidance. The verse is understood with an intrinsic meaning. These instructions lead to the need to pay attention to the cleanliness of the body and soul, and the clothes as well.

In fact, he emphasized, for those who choose to preach with the lecture method dealing with the audience or mad'u, then a preacher should have an energetic spirit. Appear to the podium with a radiant face, with neat clothes. Otherwise, it is better for him to look for other dakwah media not by lecturing.

The third clue "And that is to worship idols no matter how great or how many people worship them, leave them." He tends to interpret $a r-r u j z$, in the sense of idols. This verse outlines from the outset that whatever happens, and under whatever pretext, it is not permissible for you, O Prophet Muhammad, to accept and approve idolatry. The principle of non-negotiable faith is the pure oneness of God and worship to Him alone.

The fourth clue, "And do not confer to acquire more" QS 74:6. In line with QS 25:57 "Say: I do not ask for it any payment - only that whoever wills might take to his Lord a way".

This fourth principle is sincerity. Islam teaches a charity is not only outwardly, but also the inner aspect. In terms of outwardness, every deed must be in accordance with the guidance of the Sari'a. While the inner aspect, deeds which is carried out solely intends to seek the pleasure of Allah SWT. Which means in this context the teachings of sincerity are very important to know. From various sources, It is stated that only worship or deeds accompanied by sincerity is accepted by Him. God's Word QS: 98: 5.

Muhammad 'Aly al-ūābūny gave the view of this verse, sincerety directs all words and deeds solely because of Allah SWT (al-ūābūny 1997: 64). In line with that Buya Hamka explained worship must be to God not to associate with others, by surrender religion because of Him. All acts of worship, in short any deeds done, let it be sincere because of the mere SWT.

The sincerely soul is absolutely owned by a preacher, otherwise the dakwah cannot walk and survive. If it other objectives, dakwah will automatically fail and will not be sustainable. The task of preaching is duties of the Prophets and Apostles. The success of the Prophet delivered the message because the Prophet preached did not know the reward as well as his friends. Therefore, when a preacher expects success in his dakwah, he must have what the Prophet had, even though as human beings we certainly cannot be perfect.

M. Qurasih Shihab explained that a preacher should not consider his preaching as a gift to mad'u. With this principle, the preachers will get more. However, This is not sourced from human, but from God. Furtherly, The verse prohibits linking dakwah with the aim of obtaining worldly rewards, one example is to choose the dakwah object for the commercial reason. Religious invitations must be freed from the worldly interests of the person who invited them, such as gaining an opportunity to rule, maintain their social position, gain popularity and / or hoard material. Therefore, each preacher must be independent and established in life. To reach these goals, preacher must have a profession that can support his life as well as his dakwah task. Otherwise, the community will not respect the preacher because he has insulted himself.

The fifth principle, "And for your Lord, be patient." A person who faces obstacles in his work sometimes his little heart whispers to stop it, even though what he had expected was not yet achieved. Such a small desire is able to become a person's soul desire. If the preacher ignores from bad desires, it will be a real expression of the "patience". This means that the person will continue his effort despite facing obstacles. Therefore, patience here is the same line with being steadfast.

According to Sheikh Yusuf Qaradhawi, patience is to refrain from what is not liked in order to get the pleasure of Allah SWT. He further explained that there are two types of patience. The first is physical patience such as holding the body and staying afloat, for example hard work in worship or other work. Second, mental patience (lust) facing the demands of culture and desire of lust. Examples of the patience kind are holding hunger and sexual appetite, enduring suffering, enduring anger, facing war and keeping secrets.

The preachers need to have a high quality of patience because preaching is a struggle for "jihad." Inviting human to do something good, especially preventing ignorance or munkar, will likely get many obstacles. Abdul al-Kārīm Zaidān explained that the trials and obstacles in carrying out the dakwah such as by wordly, deception and action from the infidels are sunnatullah.

Patience here, according to M. Quraish Shihab, includes all types of patience, first, an effort to achieve what is needed. Second, facing disasters so that they receive with a large and airy soul in order to obtain the rewards and wisdom. And the last, specifically emphasized is patience in war and struggle. 
According to the writer, one of a preacher's patience result a high work ethic, earnest attitude and hard work. The dominant time is represented to think about the progress of the people. Thus he distanced himself from unwholesome. And in essence, working hard must be a personal character of Muslims, especially for the preachers. But it will not be created if there is no soul of patience.

Another principle that he underlines is the need to respect the differences of opinion in preaching. The difference in interpretation of the religious message of something cannot be denied. Even though those differences can all be true. Some experts say that what is called the decree of Allah is the result of ijtihad of a mujtahid, although it varies. It should be underlined that it is not easy, if reluctant to say 'impossible', to unify the mazhab in the sense of fusion so that Muslims only have one mazhab. Therefore, do not think or try for it. Nor to declare only one mazhab is correct and others are false, or none of mazhab. The invitation echoed was the unity of the people by allowing existing Islamic mazhab to flourish, while making approaches so that they could join hands, go hand in hand, walk and work together to achieve mutual success and support one another against common enemies.

Human weaknesses is overly passionate, so that among them are more exceeds than God, desiring all human beings have one opinion, one mazhab, one religion. This passionate is also drives him to force his absolute views to be adopted by others. In fact, God himself gives freedom to everyone to choose their own way.

\section{Dakwah Methods and Content}

God's instructions about the method of carrying out the dakwah is in QS: 16: 125. In this verse, three methods of dakwah are explained, namely wisdom, good advice and discussion in the best way. M. Quraish Shihab describes the essence of the verse is to adjust the material and the way of preaching with the target of preaching; to scholars with wisdom, ordinary people with mauizzah by giving advice and parables that touch the soul in accordance with their simple level of knowledge. As for the experts of the bible and other religions who or those who disagree with us, are ordered to be jidal/discussion in the best way, namely with logic and rhetoric that is subtle and free from violence and swearing and the purpose of finding truth, not victory. The three methods of dakwah are named al-Ittishal al Lafdzy.

He added, in order to dakwah can give the impression it should be done in front of a limited number of worshipers. He considered dakwah will be less effective if carried out in front of a large number of worshipers, such as a grand meeting, great Zikir. Likewise, because of the breadth of the dakwah field it is better for preachers to have specialists, not necessarily speaking in all fields. Since the time of the Prophet, sahabahs who had specialists have been born in various fields. There are those who pursue interpretation (tafseer), there are more hadiths, there are also matters relating to haram or slander / crisis and so forth. In the history of successful contemporary dakwah, certain figures with expertise such as Muhammad Ibn Abdu Wahhab have been born whose attention is purifying aqeedah, Muhammad Abduh, rationalizing religious teachings, Jamaluddin al-Afghani, unity of the people and struggle against invaders, Hasan alBanna, rectifying the wrong understanding in society and Al-Maududi fighting modern jahiliyah.

Related to the dakwah content, there are some dakwah materials that have been frequently delivered to the public which by M.Quraish Shihab is not approved. Among the material is an explanation regarding the journey of the Prophet Muhammad, PBUH from Mecca to Medina. These events are often described by highlighting supernatural features, such as "pigeons" and "cobwebs" that suddenly cover the mouth of the cave where the Prophet (s) hid, "leaves" which immediately dense around the cave, etc. Not all of these descriptions can be justified in terms of history, especially in scientific terms.

According to him this does not support the expected role of religion in development. He did not play down the efforts and labors of the Prophet before and during the hejrah. But obscuring history and even religious teachings. "Islam does not rely on supernatural things in proving its teachings and in achieving the ideals of its struggle." Although in essence this does not mean a denial of the "helping hand of God". He has, will and will always be.

Likewise, statements among people about Christianity and Judaization will always occur by basing their opinions on the word of Allah surah al-Baqarah verse number 120. Such understanding is refuted by the argument that such opinions are not in line with the views of contemporary scholars such as Muhammad Sayyid Tanțawi, Ibn 'Ashur, as well as past scholars such as Fakhuruddinar-Rāzi, Jalaluddin al-Mahalli and Jalaluddin al-Sayuṭi in al-Jalalain's interpretation, are also not in line with reality. Indeed, some Christians are the same with Muslims, but Jews are not because Jewish religion is not a religion of preaching, so they do not invite anyone to embrace their religion. Now, if we understand this verse according to the usual understanding above, then it contradicts this fact.

Further explained according to Muhammad SayyidȚanțawi (w 2010), the former Mufti of Egypt and Shaykh al-Azhar of Egypt, saying "until you follow their religion / millat" is kinayah, ie not explicitly mentioning what is meant, but mentioning something else which may lead to what is meant. This editorial is intended to illustrate the despair 
regarding the possibility of certain Jews and Christians embracing Islam. This is because they absolutely will not renounce their religion even though the Prophet Muhammad (PBUH) invited as hard as he could. Because how they will leave their religion, even though they are not willing unless the Prophet Muhammad followed them, whereas for the Prophet Muhammad, following their religion is impossible. If so, it is impossible for them to follow your religion, O Prophet Muhammad.

Likewise the intent of QS Ar-Rahman 55:33, this verse is used by some people as proof of the Qur'an's scientific cues about the ability of humans into space. This opinion, according to M. Quraish Shihab, is not right. His argument is that even if humans have now reached the moon or other planets, that does not mean that humans have been able to get out through the corners of heaven and earth. Added even though without regard to the context of the verse before and after the above verse, it can be stated that this verse does not talk about life before the end of the world because what is emphasized here is the inability to penetrate the corners of heaven and earth and until now no one has even succeeded in doing so. The team of authors of Tafsir al Muntakhab commented that: until now it has proven how much effort and energy is needed to be able to penetrate the earth's gravitational sphere. This clearly proves that the attempt to penetrate the sky and earth millions of light years away is impossible for jinn and humans.

Tahir Ibn Asyur asserted that the above verse is not the utterance said to them in the life of this world. This means that this will be said later on as understood from the context of the verses before and after. Therefore, the command above "Pass it!" not a command to be carried out, but a command that shows an inability to fulfill it. It is like a brave strong character who says to his cowardly weak opponent; "Shoot me!" ie you cannot possibly do it.

\section{Conclusions and Recommendations}

\section{A. Conclusion}

Through a variety of writings, M.Quraish Shihab has emulated the tradition of classical scholars who poured his thoughts not only through speech but also through writing. This led us to understand the thoughts of previous scholars even though we had never met them.

One of the things that he concerns is the implementation of dakwah. He argues that it is very important to understand that the purpose of dakwah impresses the listener both by adding and correcting mad'u understanding as well so that they can practice it in daily life. To deliver to the case, a preacher must first input himself with science through the practice of reading commands. In addition, preachers must set an example with noble morals such as sincerity, patience, brotherhood and that should not be forgotten is an attractive appearance. All of that is termed al-Ittishal Ghairu alLafdzy.

In delivering preaching da'i is expected to have knowledge about the condition of mad'u. Next step, the preacher can choose material and methods either by bil-al-hikmah, mauizhah or by jidal or discussion. Applying this theory is term of Ittishal al-Lafdzy.

In the meantime he argues, a preacher should not go down to the tastes of his listeners who judge a good dakwah that leads his listeners to laugh out loud or cry. But how is mad'u elevated position to the same level with da'i. Therefore preaching material that will be delivered in advance is examined in depth so that the material does not have a strong foundation or is contrary to the understanding of most religious leaders.

\section{B. Suggestions}

Based on the descriptions above, the writer recommends that every perpetrator of dakwah always update himself by expanding his knowledge. This aims to make dakwah in accordance with the conditions and situations of the community so that dakwah can be felt by the community as a solution in various aspects of life.

To the dakwah institution, presumably the theme of preaching is based on the situation and conditions faced by the community.

The community and the mosque management would look at dakwah as a guide and not as a spectacle, so in the matter of inviting presenters based on the expertise and material presented. Not based solely on rhetoric ability, so it is hoped that dakwah is truly beneficial in promoting knowledge, awareness and religious practice.

\section{Bibliography}

Al-Qur'an al-Karim.

A.Ilyas Ismail, 2006, ParadigmaDakwahSayyidQuthubRekonstruksiPemikiranDakwahHarakah.Jakarta: Penamadani.

Ahmad Galūsh.1978. Al-Da’wah al- Islāmiyah Usuluhāwawasāiluhāa. Kairo: Dār al-Kitaāb al Misry. 
Anwar Arifin. 2011. Dakwah Kontemporer Sebuah Studi Komunikasi.Yogyakarta:Grahallmu.

Hamka. 1999.Tafsir Al-AzharJilid 8. Singapura: PustakaNasional PteLTd.

http//putrahermanto.wordpress. com /2012/ 05 /06/ Populasi- Muslim- di-Dunia-Muslim.

JalaluddinRakhmat, 2000, Renungan-Renungan Sufistik Membuka Tirai Kegaiban: Bandung:Mizan.

M.Quraish Shihab,2009, Tafsir Al-Mishbah Pesan, Kesan dan Keserasian al-Qur'an,Volume 2.6.14 Jakarta: LenteraHati.

M.Quraish Shihab.1999. Membumikan Al-Qur'an Fungsi dan Peran Wahyu Dalam Kehidupan Masyarakat. Bandung: Mizan.

M.Quraish Shihab, 2011, Membumikan Al-Qur'an Jilid 2. Mengfungsikan Wahyu dalam Kehidupan.Jakarta: Lentera Hati.

M.Quraish Shihab. 2000. Wawasan Al-Quran: TafsirMaudhu iataspelbagaiPersoalanUmat. Bandung: Mizan.

M.Quraish Shihab. 2007. Sunnah-Syiah Bergandengan Tangan Mungkikah? Kajian Atas Konsep Ajaran Dan pemikiran.Jakarta: Lentera Hati

M.Quraish Shihab.2013. Kaidah Tafsir: Syarat, Ketentuan, dan Aturan yang Patut Anda Ketahui dalam Memahami al-Qur'an. Jakarta: Lentera Hati.

Moh.ali Aziz. 2004. Ilmu Dakwah. Jakarta:Kencana.

Al-Qaradhāwi Yusuf, 2011Fi al-Da'watilla al-lah. Kairo: Maktabat Wahbat: 2011.

Al-Qaradhawi Yusuf, 2010. Motivasi dan Pengaruh Sabar Menurut Al-Quran, Kuala Lumpur: Penerbitan Ilham Baru.

Al-Șābūny Muhammad 'Aly, 1997, Șafwatu al-Tafāsir, jillid 3. Baīrut: Dār al-Qur'ān al- Karīm.

Thomas W. Arnold, 1985,The 2011, Preaching of Islam, New York : AMS Press INC

Toto Tasmara.1997.Komunikasi Dakwah. Jakarta: Penerbit Gaya media.

Al-Wā’ iyTaufiq Yūsuf,1995,al-Da'watu 'Ila al-Lāh al-Risālatu, al-Wasīlatu al-Hadfu,Mesir: Dār al-Yaqīn.

Al- Zaidan Abdul Karim, 2000. Uṣūl al-Dakwah.Bairut-Libanon: Muassatu al-Risalah. 